\title{
THE STUDY OF EFFECT OF METAL ION Fe(III) ON THE CHLOROPHYLL AS POTENTIAL PHOTOSENSITIZER ON DYE SENSITIZED SOLAR CELL
}

\author{
H. Darmokoesoemo* , H. Setyawati, A.T.A. Ningtyas and H.S. Kusuma* \\ Department of Chemistry, Faculty of Science and Technology, Airlangga University, \\ Surabaya-60115, Indonesia \\ *E-mail: handokodarmokoesoemo@gmail.com; heriseptyakusuma@gmail.com
}

\begin{abstract}
The energy crisis is major problem facing the world today, so it takes renewable energy source that are environmentally friendly and can be renewed, one of which is Dye Sensitized Solar Cell (DSSC). DSSC is one of the photochemical electric cells that can convert solar energy into electrical energy. This research aims to study the characteristics of chlorophyll compounds with the addition of metal ions Fe(III) as well as determine the effect of metal ions $\mathrm{Fe}$ (III) on the performance of chlorophyll as photosensitizer in the DSSC. The formation of complex compounds of $\mathrm{Fe}(\mathrm{III})$-chlorophyll shown by the phenomenon of Metal Ligand Charge Transfer (MLCT) at wavelength of $263.00 \mathrm{~nm}$ and absorption transition d-d at $745.00 \mathrm{~nm}$. FTIR characterization of the binding of the Fe-O complex compounds appeared at $486.06 \mathrm{~cm}^{-1}$. The complex compounds of Fe(III)-chlorophyll has higher conductivity value than the solvent (DMSO) indicating that the complex compounds are ionic. So the presence of metal ions Fe(III) on chlorophyll can increases the potential of chlorophyll as photosensitizer on DSSC.
\end{abstract}

Keywords: Fe(III)-chlorophyll, photosensitizers, dye sensitized solar cell, metal ligand charge transfer.

(C) RASĀYAN. All rights reserved

\section{INTRODUCTION}

Energy is essential requirement for human survival. Reliance on fossil fuels cause the supply of energy sources dwindling, while demand for energy is increasing. ${ }^{1}$ The problems of the energy crisis prompted many researchers to develop technologies that generate renewable energy. Solar energy is one of renewable energy is being actively developed at this time. Applications of Dye Sensitized Solar Cell (DSSC) using dye as catcher sunlight is potential to be developed because DSSC produces electricity and its applications easily be applied to life. ${ }^{2}$

Dye or pigment of plants which is often used as photosensitizer in previous research is chlorophyll powder of Classic Mulberry Powder (CMP). Researchers have proven that chlorophyll and xanthophyll can be excited by the exposure of the dye. As the result of its development, researchers have gained the energy conversion efficiency is better on derivative of chlorophyll dye because it has carboxylic group. ${ }^{3}$ Chlorophyll as major pigment is effective as photosensitizers in the photosynthesis process of green plants which have maximum absorption at $670 \mathrm{~nm}$, so that chlorophyll is compound which is suitable for photosensitizer. ${ }^{4}$ However, the stability of chlorophyll is weak and easily decompose when exposed to heat, light, acidic and alkaline conditions. ${ }^{5}$ The performance of photosensitizer is influenced by the level of absorption peaks, if absorption peak of dye is high it indicate that the more photons energy can be absorbed and converted into electrical energy in solar cell applications. The produced current and voltage also affect the performance of the photosensitizer.

In previous studies, the formation of curcumin complex with Fe(III) to improve photostability and the antioxidant of curcumin. Curcumin interacts with Fe(III) via the carbonyl group and provide better antioxidant photostability. ${ }^{6,7}$ Interactions that occur in complex molecules characterized by the shift in wavelength bathochromic derived from electronic transition $\pi \rightarrow \pi^{*}$ and $n \rightarrow \pi^{*}$. The chlorophyll also has carbonyl group and is expected to have similar interaction with curcumin when it binds to Fe(III).

Rasayan J. Chem., 10(2), 313 -318(2017)

http://dx.doi.org/10.7324/RJC.2017.1021561 
Therefore in this research studied the effect of ion Fe(III) on the performance of chlorophyll as potential dye sensitizer on DSSC. Fe metal selected because it is transition metal in which the electron configuration $\mathrm{d}^{6}$ same as ruthenium and osmium metals (used as dye solar cell), ferrous metals more easily obtained because of its abundance in nature is much more compared to other metals, has quantum that relatively high for produce sensitization on the nanocrystalline $\mathrm{TiO}_{2}$, cheaper and can be obtained in Indonesia easily than other metals which has been studied previously as complex for solar cells, soluble in polar solvents, and its wavelength in the UV-Vis i.e. $551 \mathrm{~nm} .^{8}$

\section{EXPERIMENITAL}

\section{Materials and chemicals}

The chemicals used in this study have purity degree of pro analysis, among others: sodium hydroxide $(\mathrm{NaOH})$, ethanol $\left(\mathrm{C}_{2} \mathrm{H}_{5} \mathrm{OH}\right)$, hydrochloric acid $(\mathrm{HCl})$, iron (III) chloride $\left(\mathrm{FeCl}_{3}\right), \mathrm{TiO}_{2}$ Degussa P25, acetonitrile, hydrochloric acid $(\mathrm{HCl})$, aquabidest, electrolyte solution of $\mathrm{I}_{2}$ in $\mathrm{KI}$ and chlorophyll powder CMP (PT. Health Wealth International).

\section{Preparation of chlorophyll}

A total of $1 \mathrm{~g}$ of chlorophyll powder dissolved with aquabidest in glass beaker, then transferred into $10 \mathrm{ml}$ volumetric flask up to the mark.

\section{Saponification reaction of chlorophyll}

A total of $2 \mathrm{~g}$ of $\mathrm{NaOH}$ dissolved in $50 \mathrm{~mL}$ aquabidest, then $\mathrm{NaOH}$ solution are taken $5 \mathrm{~mL}$ and diluted in $50 \mathrm{~mL}$ of aquabidest to obtain concentration of $0.1 \mathrm{M}$. NaOH solution with concentration of $0.1 \mathrm{M}$ was taken $2 \mathrm{~mL}$ and added $8 \mathrm{~mL}$ ethanol to form ethanol-NaOH with total volume of $10 \mathrm{~mL}$. Chlorophyll solution as much as $5 \mathrm{~mL}$ added to the solution and homogenized for 2 hours in water bath at temperature of $50^{\circ} \mathrm{C}$. The addition of $\mathrm{NaOH}$ to form reaction with alkaline conditions. A total of $1 \mathrm{~mL}$ of chlorophyll taken and dissolved in $50 \mathrm{ml}$ aquabidest then checked using UV-Vis spectrophotometer1800 Shimadzu at wavelength $639.00 \mathrm{~nm} .^{5}$

\section{Preparation of complex compound Fe(III)-chlorophyll}

The chlorophyll solution is added with concentrated $\mathrm{HCl}$ of 2 drops to achieve $\mathrm{pH}$ of 2-3. Furthermore, added $\mathrm{FeCl}_{3}$ solution with concentration of $10 \%$. Furthermore, the solution with each concentration homogenized at temperature of $60-70^{\circ} \mathrm{C}$ for 1 hour, then the solution was evaporated to one-third parts and reheated until the filtrate became exhausted. Next, the precipitate is heated in the oven at temperature of $80^{\circ} \mathrm{C}$ for 24 hours to form the product $\mathrm{Fe}(\mathrm{III})$-chlorophyll. ${ }^{5}$

The characterization of complex compounds of Fe(III)-chlorophyll using UV-Vis spectrophotometer The chlorophyll solution of $1 \mathrm{~mL}$ dissolved by aquabidest in $50 \mathrm{~mL}$ volumetric flask. Furthermore, the absorbance is measured at wavelengths between 200-800 nm using UV-Vis spectrophotometer. ${ }^{9}$ The solution from saponification of chlorophyll of $1 \mathrm{~mL}$ dissolved in $50 \mathrm{~mL}$ volumetric flask with aquabidest. Then measured the absorbance at region 200-800 $\mathrm{nm}$.

\section{The characterization of complex compounds of Fe(III)-chlorophyll using FTIR}

The characterization using FTIR aims to observe the formation of bond between the metal with ligands and identify the functional groups on the formed compound. ${ }^{4}$ The complex compounds of Fe(III)-chlorophyll mixed with $\mathrm{KBr}$ then the mixture was made pellets and measured IR absorption at wave number 4000-300 $\mathrm{cm}^{-1} \cdot \cdot^{10}$

\section{The characterization of electrical conductivity of complex compound of $\mathrm{Fe}$ (III)-chlorophyll}

This characterization is aimed to determining the properties of complex compounds of Fe(III)-chlorophyll that dissolved in dimethyl sulfoxide (DMSO) at concentration of $10^{-4} \mathrm{M}$. The electrical conductivity of complex compounds will be compared with the electrical conductivity of DMSO using conductometer. 
RASĀYAN J. Chem.

Vol. 10 | No. 2 |313 -318 | April - June | 2017

\section{RESULTS AND DISCUSSION}

The complex compounds that have been made were characterized to determine the properties and characteristics. The characterization is conducted using UV-Vis spectrophotometer, FTIR, and conductometer.

The characterization of complex compounds of Fe(III)-chlorophyll using UV-Vis The characterization using UV-Vis spectrophotometer is conducted to determine the absorption maximum wavelength in the wavelength range $200-800 \mathrm{~nm}$. The characterization results with UV-Vis spectrophotometer is shown in Table 1.

Table-1: The characterization result of complex compounds of Fe(III)-chlorophyll and chlorophyll

\begin{tabular}{l|l|l|l|l}
\hline \multicolumn{1}{c|}{ Compounds } & \multicolumn{4}{c}{ Maximum wavelength (nm) } \\
\hline Fe(III)-chlorophyll & 263.00 & - & - & 745.00 \\
\hline chlorophyll & - & 404.00 & - & 628.50 \\
\hline
\end{tabular}

Table-1 shows that there is difference between the maximum wavelength of the complex compound of $\mathrm{Fe}$ (III)-chlorophyll and chlorophyll. The maximum wavelength of the complex compound of Fe(III)chlorophyll is $263.00 \mathrm{~nm}$ and $745.00 \mathrm{~nm}$, while the maximum wavelength of the chlorophyll is $404.00 \mathrm{~nm}$ and $628.50 \mathrm{~nm}$. The difference of maximum wavelength that emerged showed that the complex compounds of Fe(III)-chlorophyll has been formed. In the complex compounds of Fe(III)-chlorophyll the maximum wavelength in the UV and Visibel region is at $263.00 \mathrm{~nm}$ and $745.00 \mathrm{~nm}$. The maximum wavelength which appears at region 200-300 $\mathrm{nm}$ due to the phenomenon of charge transfer in the form Metal to Ligand Charge Transfer (MLCT). In the complex compounds of Fe(III)-chlorophyll occurred these phenomena because metal ion Fe(III) has lower oxidation states. ${ }^{11}$ The wavelength of MLCT on complex compounds of Fe(III)chlorophyll can be used as dye sensitizer in DSSC due to the phenomenon of charge transfer. The maximum wavelength of compound is also influenced by the transition $\mathrm{d}-\mathrm{d}$ that appearing on visible areas. ${ }^{12}$ This transition is changing the distribution of metal-ligand charge because the electron density shifts from orbital with high metal character to high ligand orbitals. This phenomenon is included in the phenomenon of MLCT. ${ }^{13}$ MLCT phenomenon occurs due to ligand has orbital $\pi^{*}$ with low energy and the presence of MLCT phenomenon on the complex compound cause the complex compound is very well be used as dye sensitizer because it can absorb light with optimal so that it can be converted into electrical energy. When a compound has a lot of electrons in d orbitals and amount of ligand is abundant it cause the compounds are able to suffer the MLCT phenomenon. ${ }^{13}$

In this study, Fe(III)-chlorophyll dissolved in dimethyl sulfoxide (DMSO) as solvent because this solvent has high degree of polarity. In addition DMSO also not liberate hydrogen when met with very electropositive metal. ${ }^{14}$

\section{The characterization of complex compounds of Fe(III)-chlorophyll using Fourier Transform Infrared (FTIR)}

The characterization of complex compounds of Fe(III)-chlorophyll by Fourier Transform Infrared (FTIR) is to determine the functional groups and the formed bond between metal and ligands. The differences in the FTIR spectra between chlorophyll as ligand with the complex compound of Fe(III)-chlorophyll indicates that the compound has been successfully synthesized. The characterization results of chlorophyll as ligand and complex compound Fe(III)-chlorophyll can be seen in Figure-1 with the FTIR data can be seen in Table- 2 .

Based on the FTIR spectra from Figure-1 and FTIR data from Table-2 there is bond between the metal $\mathrm{Fe}$ (III) with chlorophyll as ligand. It can be known from the formation of Fe-O bond, so it can be concluded that the complex compounds of Fe(III)-chlorophyll has been formed. The prediction bonding between the metal Fe(III) with chlorophyll as ligand is shown in Figure-2. 
RASĀYAN J. Chem.

Vol. 10 | No. 2 |313 -318 | April - June | 2017

The electrical conductivity characterization of complex compound of $\mathrm{Fe}$ (III)-chlorophyll using conductometer

The characterization of electrical conductivity of complex compounds using conductometer aims to determine the type of complex compound whether molecular or ionic. The complex compounds that have measured the electrical conductivity is then compared with the electrical conductivity of used solvent is DMSO. If the conductivity value of complex compounds of $\mathrm{Fe}$ (III)-chlorophyll is higher than the solvent (DMSO), this indicates that the complex compound is an ionic compound. But if conductivity value of the solvent (DMSO) is higher than the complex compound, this indicates that the complex compound is molecular compound. The conductivity value are shown in Table-3.

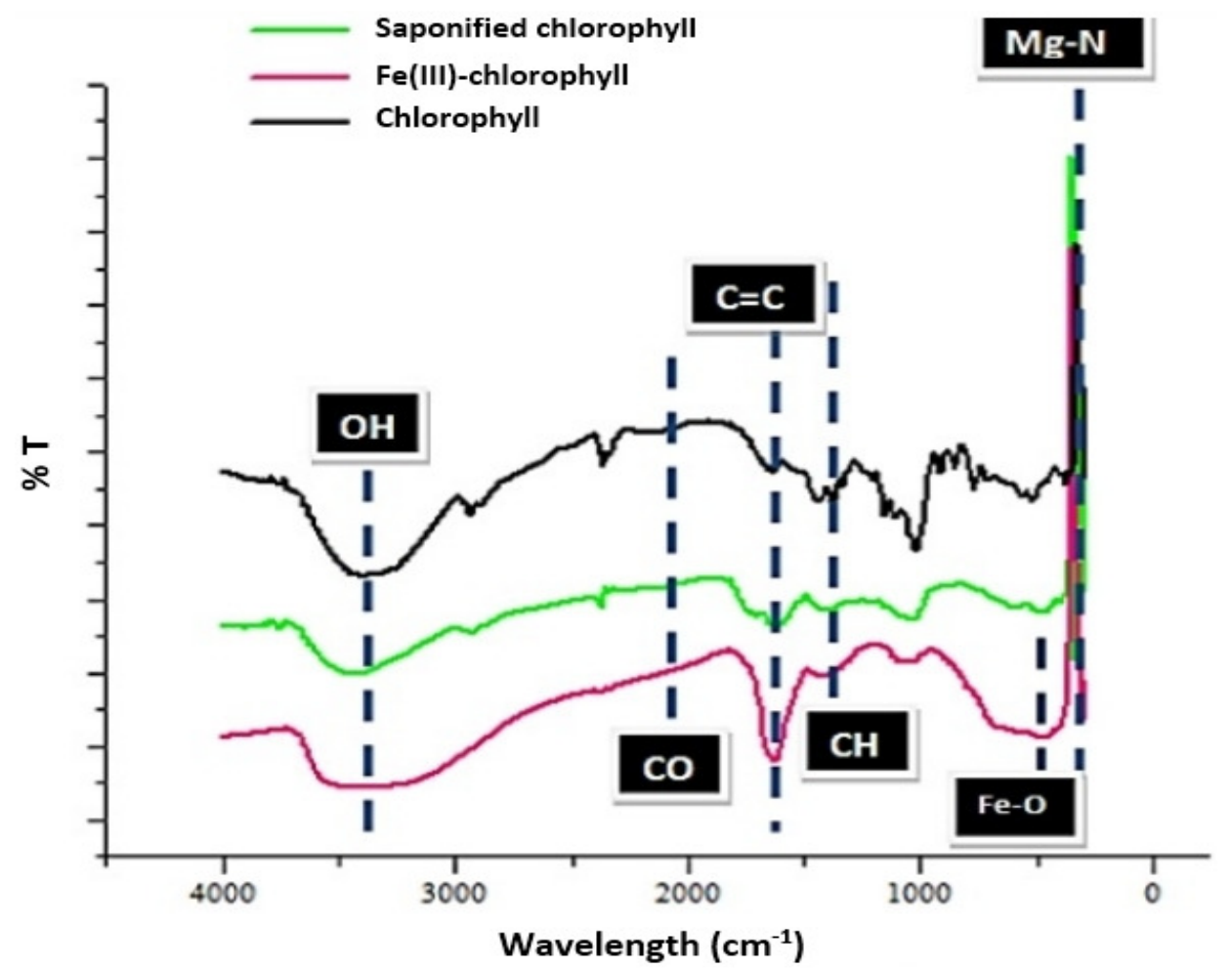

Fig.-1: FTIR spectra of chlorophyll, saponified chlorophyll and complex compounds of Fe(III)-chlorophyll

Table-2: The FTIR data of ligand and complex compound

\begin{tabular}{c|c|c|c|c}
\hline Bond & $\begin{array}{c}\text { Wavelength of } \\
\text { ligand }\left(\mathrm{cm}^{-1}\right)\end{array}$ & $\begin{array}{c}\text { Wavelength of complex } \\
\text { compound }\left(\mathrm{cm}^{-1}\right)\end{array}$ & $\begin{array}{c}\text { Wavelength } \\
\text { Theoretically }\left(\mathrm{cm}^{-1}\right)\end{array}$ & Reference \\
\hline $\mathrm{Fe}-\mathrm{O}$ & - & 486.06 & $430-480$ & $\begin{array}{c}\text { Darmokoesoemo } \text { et al., } \\
2017 \mathrm{a}\end{array}$ \\
\hline $\mathrm{Mg}-\mathrm{N}$ & 300.9 & 308.61 & $242-310$ & $\begin{array}{c}\text { Darmokoesoemo } \text { et al. }, \\
2016 \mathrm{a}\end{array}$ \\
\hline $\mathrm{OH}$ & 3394.72 & 3402 & $3362-3421$ & $\begin{array}{c}\text { Darmokoesoemo } \text { et al. }, \\
\text { 2016b }\end{array}$ \\
\hline $\mathrm{CO}$ & 2167.99 & 2167.99 & $2150-2200$ & $\begin{array}{c}\text { Darmokoesoemo } \text { et al. }, \\
2016 \mathrm{a}\end{array}$ \\
\hline $\mathrm{CH}$ & 1381 & 1381 & $1350-1400$ & $\begin{array}{c}\text { Darmokoesoemo } \text { et al. }, \\
2017 \mathrm{~b}\end{array}$ \\
\hline $\begin{array}{c}\mathrm{C}=\mathrm{C} \\
\text { aromatic }\end{array}$ & 1635 & 1620 & $1619-1640$ & $\begin{array}{c}\text { Darmokoesoemo } \text { et al., } \\
2017 \mathrm{c}\end{array}$ \\
\hline
\end{tabular}




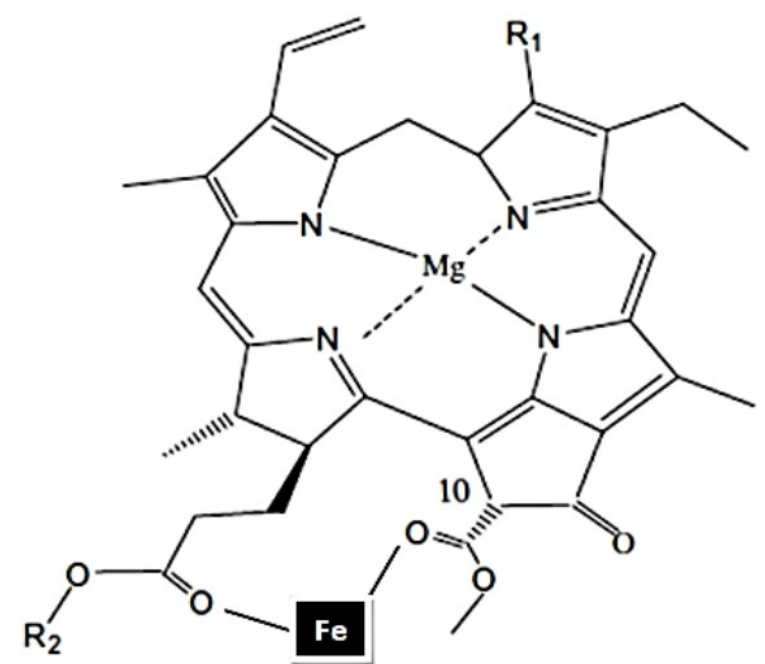

Fig.-2: The prediction bonding between the metal Fe(III) with chlorophyll as ligand

Table-3: The conductivity value of complex compounds and DMSO

\begin{tabular}{l|l}
\hline \multicolumn{1}{c|}{ Compounds } & \multicolumn{2}{c}{ Conductivity $(\mu \mathrm{s})$} \\
\hline Solvent (DMSO) & 0.08 \\
\hline Fe(III)-chlorophyll in the solvent (DMSO) & 2.05 \\
\hline
\end{tabular}

Based on Table-3 it can be seen that the conductivity of the complex compound of Fe(III)-chlorophyll is higher than the solvent (DMSO) indicating that the complex compounds are ionic. Ionic compounds easily conduct electricity because it has high boiling point and melting point. Moreover the ionic compound is also easy to break down into ions due to the electron transfer process can take place continuously so it is good to be applied in DSSC. ${ }^{15}$

\section{CONCLUSION}

The characterization of chlorophyll compounds with the addition of metal ions Fe(III) using UV-Vis spectrophotometer showed the presence of Metal Ligand Charge Transfer (MLCT) phenomenon at maximum wavelength of $263.00 \mathrm{~nm}$. In the FTIR spectrum, the complex compounds showed the presence of Fe-O vibration of chlorophyll as ligand at wavenumber of $436.06 \mathrm{~cm}^{-1}$. Based on the electrical conductivity test can be seen that the formed complex compounds is ionic compound. Moreover the presence of metal ions Fe(III) on chlorophyll can increases the potential of chlorophyll as photosensitizer on Dye Sensitized Solar Cell (DSSC).

\section{REFERENCES}

1. R. Ardianto, W.A. Nugroho and S.M. Sutan, Jurnal Keteknikan Pertanian Tropis dan Biosistem (in Bahasa Indonesia), 3(3), 325 (2015).

2. S.K. Swami, N. Chaturvedi, A. Kumar, R. Kapoor, V. Dutta, J. Frey, T. Moehl, M. Gratzel, S. Mathew and M.K. Nazeeruddin, Journal of Power Sources, 275, 80 (2015).

3. Y. Koyama, T. Miki, X-F. Wang and H. Nagae, International Journal of Molecular Sciences, 10, 4575 (2009).

4. Y. Amao, Y. Yamada and K. Aoki, Journal of Photochemistry and Photobiology A: Chemistry, 164, 47 (2004).

5. J. Han, Y. Wang, J. Ma, Y. Wu, Y. Hu, L. Ni and Y. Li, Separation and Purification Technology, 115, 51 (2013).

6. M.S. Refat, Spectrochimica Acta Part A: Molecular and Biomolecular Spectroscopy, 105, 326 (2013).

7. X.-Z. Zhao, T. Jiang, L. Wang, H. Yang, S. Zhang and P. Zhou, Journal of Molecular Structure, 984, $316(2010)$. 
8. J. Sokolowska-Gajda, H.S. Freeman and A. Reife, Dyes and Pigments, 30(1), 1 (1996).

9. M.S.W. Kumara and G. Prajitno, Preliminary studies fabrication of Dye Sensitized Solar Cell (DSSC) using extraction of leaf spinach (Amaranthus hybridus L.) as dye sensitizers with variations distance light source on DSSC (in Bahasa Indonesia), Thesis, Institut Teknologi Sepuluh Nopember, Surabaya (2012).

10. P. Balraju, M. Kumar, M.S. Roy and G.D. Sharma, Synthetic Metals, 159(13), 1325 (2009).

11. G.L. Miessler, P.J. Fischer and D.A. Tarr, Inorganic chemistry, 5th ed., Prentice-Hall, Englewood Cliffs (2014).

12. M. Yuniyanto, Opthode performance study of metal ions $\mathrm{Zn}$ (II) and $\mathrm{Cr}$ (III) without plasticizers from aminopropiltrimetoksisilan and oktiltrietoksisilan with chromoionofor 4- (2-piridilazo)resorcinol (in Bahasa Indonesia), Thesis, Faculty of Mathematics and Natural Sciences, Universitas Sebelas Maret, Surakarta (2006).

13. R. Xue, P. Behera, J. Xu, M.S. Viapiano and J.J. Lannutti, Sensors and Actuators B: Chemical, 192, 697 (2014).

14. R. Vignes, Dimethyl Sulfoxide (DMSO) a "new" clean, unique, superior solvent, American Chemical Society, Annual Meeting, August 20-24, 2000, Washington DC (2000).

15. W. Illiya and F. Martak, Synthesis and characterization of complexes compound of metal cobalt(II) with 2-phenylethylamine (in Bahasa Indonesia), Thesis, Institut Teknologi Sepuluh Nopember, Surabaya (2011).

16. H. Darmokoesoemo, A.R. Fidyayanti, H. Setyawati and H.S. Kusuma, Korean Chemical Engineering Research, 55(1), 19 (2017a).

17. H. Darmokoesoemo, F.R. Setianingsih, T.W.L.C. Putranto and H.S. Kusuma, Rasayan Journal of Chemistry, 9(4), 550 (2016a).

18. H. Darmokoesoemo, Magdhalena, T.W.L.C. Putranto and H.S. Kusuma, Rasayan Journal of Chemistry, 9(4), 680 (2016b).

19. H. Darmokoesoemo, N. Widayanti, M. Khasanah and H.S. Kusuma, Rasayan Journal of Chemistry, 10(1), 54 (2017b).

20. H. Darmokoesoemo, L. Kustyarini, M. Khasanah and H.S. Kusuma, Rasayan Journal of Chemistry, 10(1), 64 (2017c).

[RJC-1561/2017] 